\title{
Foreign Aid and Economic Growth
}

\author{
Farheen Fatima \\ School of Economics, Quaid-i-Azam University, Islamabad, Pakistan \\ Email: $\underline{\text { fatima777@yahoo.com }}$ \\ Received 11 April 2014; revised 16 May 2014; accepted 20 June 2014 \\ Copyright (C) 2014 by author and OALib. \\ This work is licensed under the Creative Commons Attribution International License (CC BY). \\ http://creativecommons.org/licenses/by/4.0/ \\ (c) (i) Open Access
}

\begin{abstract}
This paper represent the study about the impact of foreign aid on the economic growth of Pakistan by taking into consideration previous studies done on the same topic for different developing countries. As results show that if aids are properly allocated in desired section which in real need development than it can prove fruitful but normally aid given to such countries always have some objective behind that with already defined section where that aid should be utilized, but if such countries are given free hand to use them they can use them in their desired section and can have more appropriate and better results in their development. Also in such countries there come the prospect of corruption if corruption is properly removed form the roots of that economy than it necessarily have better developmental result on its economy.
\end{abstract}

\section{Keywords}

Aid Effectiveness, Developing Countries, Economic Growth, Foreign Aid, Inflation Rate

Subject Areas: Business and Economics Education, Development Economics

\section{Introduction}

In an economy where the demand of investment cannot be met entirely by domestically generated savings neither through imports financed by the country's own export earnings, resources are transferred from abroad in the form of either loans, credits, grants, remittances, or direct private foreign investment. This is the traditional "two-gap" or dual approach to the analysis of the role of foreign aid in economic development where foreign resources are assumed to fill both a saving-investment gap as well as a foreign exchange gap in the recipient country.

Pakistan, like many other developing countries, stands dependent upon foreign assistance, particularly for its development needs, due to low domestic resource mobilization. Flows of savings from developed to non-developed economies have traditionally taken the form of grants and loans. The aid injection in theory brings rapid economic growth. Successful aid experiences suggest countries achieving faster physical and human capital accumulation, and in some instances improved welfare levels. There are also negative effects of foreign aid in aid recipient countries, which divert a large part of their funds (foreign assistance) to non-development public ad- 
ministration, defenses expenditure and debt servicing. Furthermore, political instability, frequent changes in policies, misaligned public-sector priorities and inefficiency of institutions neutralize the effect of aid on growth, thereby having less than the expected impact on poverty reduction.

Foreign aid or (development assistance) is often regarded as being too much, or wasted on corrupt recipient governments despite any good intentions from donor countries. In reality, both the quantity and quality of aid have been poor and donor nations have not been held to account. There are numerous forms of aid, from humanitarian emergency assistance, to food aid, military assistance, etc. Development aid has long been recognized as crucial to help poor developing nations grow out of poverty.

Foreign aid to developing countries is a subject of heated debate among politicians, economists, and development specialists. Does aid promote economic growth and reduce poverty? Some argue that foreign aid has no effect on growth and may sometimes even undermine growth in aid recipient countries. Others suggest that foreign aid positively influences economic growth. Still others suggest that foreign aid has a positive impact on growth but this impact is conditional on a good institutional and policy environment. This debate has high stakes, given that foreign aid in the form of official development assistance (ODA) by leading donor nations reached over US $\$ 120$ billion in 2010, the highest level ever recorded.

Generally, it was assumed that most of the developing countries have inadequate levels of savings and Investment and foreign aid can complement domestic savings, which could be concentrating toward investment. In this study, we assume that all foreign aid will be allocated for investment and further economic growth purposes. Poor countries also face the problem of insufficient export earnings required to import capital goods for investment. Most of the developing and under developed countries do not have the potential capacity to generate revenue to cover the minimum substantial level of public investment. In this regard, the foreign aid is seen as essential tool to fill this gap in developing countries.

Due to the importance of this topic, the impact of foreign aid has been the subject of very extensive investigation. The key question that both the donor and the recipient countries question is whether aid has any effect on developing countries' growth and their level of poverty. This issue has been approached from various perspectives; nevertheless, a single and definite answer still does not exist. Therefore, it is important to note that not only factors such as the amount and type of financial aid impact the effectiveness of available funds but also the appropriate use of these funds by the receiving country plays a vital role.

The paper is structured as follows: The next section presents a survey of literature, whereas Section 3 presents the specification of the econometric model. The next section represents methodology than in section 5 variable description and data source. The empirical results are presented and discussed in Section 6 and finally, Section 7 summarizes the main results and conclusions.

\section{Literature Review}

There seems to be extensive work examining the relation between aid and economic growth. The results from these various studies are mixed (some suggest as negative relationship; some others suggest a positive association). Under this section of the study, we provide a review of the findings of the major studies including the recent dimension into the relationship between aid and growth. Yet it seems that sixty years later, the lesser developed countries (LDCs) of the world continue to suffer from economic hardship, raising questions of whether foreign aid is a worthwhile and effective approach to boosting growth and development in recipient economies. Then how does foreign aid affect growth?

Foreign aid is normally subject to certain limitations, which reflect the motives of the donors as to how much they are sincere to the development and welfare of the developing countries. Likewise, greater foreign aid inflows have a beneficial effect on LDC growth, conditional on a stable macroeconomic policy environment in those countries [1]. Results also suggested however that there is an optimal aid allocation in terms of growth effects: while low amounts of aid do not appear to generate faster growth, very high aid/GDP ratios are also associated with slower growth. So we are willing to find out that up to which extent (or \% of GDP) aid should be given to sincerely help the developing countries, (especially with reference to Pakistan) instead of trapping them by giving them minute and useless amount of aid.

Poverty-efficient allocation of aid and compared it with actual aid allocations. The allocation of aid that has the maximum effect on poverty depended on the level of poverty and the quality of policies [2]. Finally, it is founded that the actual allocation of aid was radically different from the poverty efficient allocation. 
Among others, however, failed to find a significant relationship between development aid and economic growth. Studies on the other hand, suggested that foreign aid might have a negative impact on economic growth [3].

Likewise neglected sector of mineral development, oil and gas, water resources need special attention of donors, which being an important natural resource of Pakistan has been neglected and could not be properly exploited [4].

In this context earlier-generation work was in accordance with the new and recent generation of aid effectiveness studies [5]. Thus, less importance should be attributed to the "micro-macro paradox" as an overall appraisal of aid effectiveness. In terms of magnitude, it found that aid has less effect on growth in the short-run than in the long-run.

The study attempted to add a piece to the aid effectiveness puzzle by evaluating aid effectiveness in a production theory context [6]. By attempting to establish how well a country is using its resources. This was measured by means of an efficiency index which reflects the production ability of a country.

The sound economic management policy in terms of low inflation, trade openness and low budget deficit is crucial for aid effectiveness. There is need to implement appropriate policy measure, in order to achieve the positive impact of foreign aid on economic growth through minimizing budgetary deficits, lower the inflation rate and to achieve trade openness [7].

The growth impact of official development assistance to developing countries; results indicated that developmental aid promotes long run growth. The effect was significant, large and robust to different specifications and estimation techniques [8].

Aid effectiveness attempts to measure the contribution of foreign aid to the growth of developing countries. The impact of aid on growth could be positive, negative, or even non-existent. This contradiction is known as the "micro-macro paradox".

The effectiveness of foreign aid in sustaining economic growth and development has long been a major research topic in applied economics. Empirical evidence on this issue, however, remains mixed. Several studies provided empirical evidence in support of aid effectiveness, at least in certain macroeconomic environments and under certain conditions [8].

The effectiveness of aid, focusing on the ongoing debate on the interactive effect of aid and policy on sustainable economic growth [9]. Main findings were that foreign aid and real GDP have a negative relationship, while the aid-policy interactive term and real GDP growth have a positive and significant relationship.

Aid flows have significant impact on economic growth in Nigeria. In that case foreign aids had shown positive relation with Nigeria's economic growth, as increase in domestic investments has positive effect on economic growth of a country [10].

In short, we can conclude on the review of the above literature on the aid effectiveness in Pakistan that foreign aid has stimulated the economic growth on one hand and has substituted the domestic savings on the other hand. And it caused a severe debt serving problems in Pakistan. Accordingly, aid has a positive impact on growth in developing countries with good policies. In the presence of poor policies, on the other hand, aid has no positive effect on growth.

\section{Analytical Frame Work}

The main role of foreign aid in stimulating economic growth is to supplement domestic sources of finance such as savings, thus increasing the amount of investment and capital stock. As Morrissey (2001) points out, there are a number of mechanisms through which aid can contribute to economic growth, including 1) aid increases investment, in physical and human capital; 2) aid increases the capacity to import capital goods or technology; 3) aid does not have indirect effects that reduce investment or savings rates; and aid is associated with technology transfer that increases the productivity of capital and promotes endogenous technical changes and results in economic growth [7].

Foreign aid is used as to fill both a savings-investment gap and a foreign exchange gap in the LDCs. Foreign aid stimulates economic growth through building infrastructure, supporting productive sectors such as agriculture and manufacturing and bringing new ideas and technologies, it strengthens the important sectors, such as education, health, environment and political systems, aid is used to support subsistence consumption of food, and aid help to stabilize the economy following economic shocks and results in economic growth [9]. 
Aid flows has significant impact on economic growth in Nigeria, domestic investment increased in response to aid flows and population growth has no significant effect on aid flows. The significant coefficients of all exogenous variables clearly state that Nigeria's economy growth rate of GDP depends on inflation, foreign aid, investment and public expenditure in the short run. Above all, foreign aid to the Nigerian economy has positive impact on growth of GDP [10].

\section{Regression Specification}

In my paper I have taken nearly the same variables based regression model as was taken in the previous studies. So our regression model is given as:

$$
\mathrm{GGDPc}=\beta_{0}+\beta_{1}\left(\frac{\mathrm{INV}}{\mathrm{GDP}}\right)_{i t}+\beta_{2}\left(\frac{\mathrm{AID}}{\mathrm{GDP}}\right)_{i t}+\beta_{3}\left(\frac{\mathrm{AID}}{\mathrm{GDP}}\right)^{2}+\beta_{4} \ln (\mathrm{GDP})_{i t}+\beta_{5}(\mathrm{INF})+\mathrm{U}
$$

where GGDP is the growth rate of real GDP per capita of country in year, INV is the investment of country in year, AID is the official developmental assistance and aid received by country in year, GDP is the initial level of GDP of country, and INF is the inflation rate of country in year. The growth rate of population is a proxy for the growth rate of labor force, and the investment/GDP ratio represents the growth rate of capital stock. Where country is Pakistan and years range is from 1980 to 2012. As " $t$ " represent the time period taken and " $i$ " represent the country taken which is Pakistan.

\section{Methodology}

In Methodology we will discuss that how we have transformed our data according to our model and how all variables are correlated with each other and by its descriptive statistics we show that whether data is normally distributed.

\subsection{Data Transformation}

We have taken the data of Pakistan from 1980-2012 of GDP. Inflation rate, Aid and Investment (gross fixed capital formation). As GDP cannot be interpreted as normally so we have converted it into GDP per capita and by taking its log and then difference we have turned it into growth rate of GDP. investment data was unavailable for Pakistan so we have taken (INV/GDP) which shows the gross fixed capital formation. Aid is the official development assistance and aid received which is converted into real terms by dividing it by GDP, so now all the data has transformed into an interpretable form. Complete data is presented in appendix.

\subsection{Correlation}

The following table shows the correlation of GGDPc with Aid and Investment and Inflation rate, Aid and Investment has transformed into real terms by dividing them by GDP.

As it is presented in the Table 1 that Aid and GGDPc are negatively correlated as 1 unit change in Aid results in -0.0628 units decline in GGDPc same is with the square of Aid as 1 unit change in square of Aid results in -0.196417 units decline in growth of GDP per capita, Inflation rate is also negatively correlated 1 unit change in inflation rate results in -0.021066 unit reduction in gross domestic product. Only investment and GDP are positively correlated 1unit change in investment results in 0.214566 units increase in GGDPc. So the results show that there is very weak or nearly no correlation between GGDPc and AID/GDP ratio. So before applying any econometric method from correlation results we can say that there will be no significant impact of aid on growth.

\subsection{Descriptive Statistics}

Descriptive statistics describe the data. They do not draw conclusions about the data. Descriptive statistics are normally applied to a single variable at a time. They can tell the researcher the central tendency of the variable, meaning the average score of a participant on a given study measure. Finally, descriptive statistics can be used to tell the researcher the frequency with which certain responses or scores arise on a given study measure. Table 2 present the descriptive stats. 
Table 1. Correlation of independent variables.

\begin{tabular}{ccccc}
\hline & AID/GDP & (AID/GDP) ${ }^{2}$ & GGDPc & INF \\
\hline AID/GDP & 1.000000 & 0.965050 & -0.062897 & 0.206789 \\
$($ AID/GDP) & 0.965050 & 1.000000 & -0.196417 & 0.158116 \\
GGDPc & -0.062897 & -0.196417 & 1.000000 & -0.021066 \\
INF & 0.206789 & 0.158116 & -0.021066 & 1.000000 \\
INVRGDP & -0.288333 & -0.264946 & 0.214566 & -0.300178 \\
\hline
\end{tabular}

Table 2. Descriptive statistics of all the variables.

\begin{tabular}{|c|c|c|c|c|c|}
\hline & AID/GDP & $(\mathrm{AID} / \mathrm{GDP})^{2}$ & GGDPc & INF & INV/GDP \\
\hline Mean & 0.055535 & 0.004442 & 0.007981 & 9.036881 & 16.24660 \\
\hline Median & 0.044833 & 0.002010 & 0.008187 & 7.844265 & 16.96081 \\
\hline Maximum & 0.153900 & 0.023685 & 0.027767 & 26.66303 & 19.23542 \\
\hline Minimum & 0.011625 & 0.000135 & -0.009811 & 3.148261 & 11.43511 \\
\hline Std. dev. & 0.037418 & 0.005728 & 0.008667 & 5.515309 & 1.859314 \\
\hline Skewness & 0.994829 & 1.859650 & -0.055331 & 1.673472 & -0.943355 \\
\hline Kurtosis & 3.175014 & 5.800339 & 2.825249 & 5.625065 & 3.317199 \\
\hline Jarque-Bera & 5.485385 & 29.80324 & 0.058828 & 24.87787 & 5.032897 \\
\hline Probability & 0.064397 & 0.000000 & 0.971014 & 0.000004 & 0.080746 \\
\hline Observations & 33 & 33 & 33 & 33 & 33 \\
\hline
\end{tabular}

As it does not give the final results but from its values we can understand the nature of the data and same is with kurtosis values, probability values also show that AID, investment and inflation rate will give significant results.

\subsection{Inferential Statistics}

Ho = foreign aid has positive impact on economic growth.

$\mathrm{H} 1$ = foreign aid do not have positive impact on economic growth.

If $\mathrm{f}$-stats values will be greater than 0.1 then we will accept our null hypothesis and our results will be insignificant and vice versa.

\section{Variable Description and Data Source}

The economic growth rate for Pakistan is measured in this study as the growth of real GDP per capita in constant (2005) US dollars. The data on real GDP are from the World Bank, World Development Indicators database. The growth rate of population is used as a proxy for the growth rate of the labor force. The data on population are from the World Bank, World Development Indicators database. The investment/GDP ratio is used as a proxy for the growth rate of the capital stock. Since the investment/GDP ratio is not reported for Pakistan so, gross fixed capital formation as a share of GDP is used to represent investment/GDP ratio. The data on foreign aid are Net official development assistance and official aid received (constant 2011 US\$) from the World Bank, World Development Indicators database. Inflation rate is defined as the annual percentage change in Consumer Price Index (CPI). The data on inflation rate are from the World Bank, World Development Indicators database. For all the variables we have taken the data ranging from 1980 to 2012.

\section{Empirical Results}

The OLS procedure is employed for estimating model Equation (1) for Pakistan using annual data over the period 1980-2012. Table 3 present some major results obtained after running our model. 
Table 3. Simple estimated results of our model by OLS method.

\begin{tabular}{ccccc}
\hline Variable & Coefficient & Std. error & t-statistic & Prob. \\
\hline C & -0.004765 & 0.125281 & -0.038036 & 0.9699 \\
AID/GDP & 0.430285 & 0.268307 & 1.603702 & 0.1204 \\
INF & $-6.54 \mathrm{E}-05$ & 0.000269 & -0.243632 & 0.8094 \\
INV/GDP & 0.001131 & 0.000854 & 1.324804 & 0.1963 \\
(AID/GDP) ${ }^{2}$ & -2.977500 & 1.282558 & -2.321532 & 0.0280 \\
LNGDP & -0.005902 & 0.045253 & -0.130414 & 0.8972 \\
\hline
\end{tabular}

$\mathrm{R}^{2}$ show the strength of the model, value of R-square 0.328106 show that model's health is not so good and it has low strength, value of Durbin-Watson 2.172494 show that there is no auto-correlation in our model and f-statistic 0.045724 (less than 0.1) showing significant results. So from its results we can further improve our model by removing issue of non-stationarity if there is in any of our variable and then regress it again. Probability values of variables show that AID/GDP value is 0.1204 which show significant impact and (AID/GDP) ${ }^{2}$ also show its significance while that of other variables do not show that much significant results. So there seems to be contradiction between correlation results and model results. So it could be because of the non-stationarity problem. So we have to remove it. After correction results are presented as Table 4.

After adjusting endpoints and applying auto-regressive and moving average test to remove the issue related to the stationarity of time series data strength of the data has improved to 0.761852 and has turn our results to be highly significant as f-statistic has improved to be 0.000004 and Durbin-Watson is 2.102321 showing no autoregression, so now our model seems to be perfect. By applying AR(1) and MA(1) auto-regressive and moving average method, strength, health and significance of our model has been improved. As it is now clear from the probability values that except LNGDP value all variables are significant and $\mathrm{R}^{2}$ value has also increased to 0.761852 so now we can say that model show effective results as 1 unit change in growth (GGDP) bring 0.5 unit change or $50 \%$ change in AID/GDP ratio.

\section{Conclusions}

Foreign aid effectiveness is a very critical and unsettled issue at the theoretical and empirical level. Most of the foreign aid components diverted from development to non-development expenditures, have produced hardly any significant impact on economic growth. The model is estimated using OLS estimation approach over the period 1980-2012 for Pakistan. Result suggests that foreign aid neither at aggregate nor at disaggregate level influenced economic growth in Pakistan. As it shows that instead of aid actually investments (domestic) have positive impact on the economic growth of Pakistan. As aid given on the name of development assistance is not properly utilized for development purposes. So instead of aid Pakistan should think of increasing its domestic savings and investments.

The finding implies that foreign aid is not a blessing. Further the demerits of foreign aid that include but are not limited to; harsh covenants from donors that times even call for compromising the autonomy of the Nation, corruption within the government, fiscal imprudence and poor institutions turn foreign aid into a curse. Therefore, we can say that foreign aid is not a blessing but a curse for Pakistan.

Other variables such as, investment exerts positive and significant impact on economic growth at the aggregate and disaggregate level. The results imply that domestic investments have made an important contribution to economic growth in Pakistan.

On the negative side, aid seemed to have substituted for domestic savings, increase debt burden. As the various debt indicators depicts that Pakistan's debt burden increased over time and the country may caught in severe debt servicing problem if the macroeconomic management, foreign trade and domestic saving policies are not designed and implemented appropriately.

The policies are also important in the effectiveness of foreign aid, as the aid has a more positive impact on growth in with good fiscal, monetary, and trade policies. In the presence of poor policies, on the other hand, aid has no positive effect on growth. Accordingly, there is a need of not only good policies but also the implementation of these policies as well as the proper monitoring of the aid-utilizing projects is necessary in order to avoid 
Table 4. After adjusting endpoints convergence achieved after 20 iterations.

\begin{tabular}{ccccc}
\hline Variable & Coefficient & Std. error & t-statistic & Prob. \\
\hline C & -0.055050 & 0.072504 & -0.759264 & 0.4551 \\
AID/GDP & 0.540999 & 0.139141 & 3.888123 & 0.0007 \\
INF & -0.000354 & $9.98 \mathrm{E}-05$ & -3.544204 & 0.0017 \\
INV/GDP & 0.000649 & 0.000296 & 2.189194 & 0.0385 \\
(AID/GDP) ${ }^{2}$ & -2.985322 & 0.591792 & -5.044543 & 0.0000 \\
LNGDP & 0.015044 & 0.026151 & 0.575264 & 0.5705 \\
AR(1) & -0.145566 & 0.180060 & -0.808430 & 0.4268 \\
MA(1) & -0.989573 & 0.000673 & -1470.387 & 0.0000 \\
\hline
\end{tabular}

the misutilization and the mismanagement of the foreign capital resources. Consequently we can say, the aid may be helpful in boosting economic growth only under the presence of appropriate monetary, fiscal and the trade policies.

The major point emerging from this study is that foreign aid has positive impact on economic growth of Pakistan conditional on sound macroeconomic policies. Based on the empirical results we find that foreign aid and real GDP has negative relationship.

Our finding suggests that sound economic management policy in terms of low inflation, trade openness and low budget deficit is crucial for aid effectiveness. There is need to implement appropriate policy measure, in order to achieve the positive impact of foreign aid on economic growth through minimizing budgetary deficits, lower the inflation rate and to achieve trade openness. Aid inflow is a highly unstable and unpredictable source of external financing and it is always depend on donor's strategic interest. Policy makers take into account the stable and sustainable sources of external financing like exports, FDI and portfolio investment for stimulating growth of economy.

\section{References}

[1] Durbarry, R., Gemmell, N. and Greenaway, D. (1998) New Evidence on the Impact of Foreign Aid on Economic Growth. CREDIT Research Paper No. 98/8.

[2] Collier, P. and Dollar, D. (2001) Aid Allocation and Poverty Reduction. European Economic Review, 46, $1475-1500$. http://dx.doi.org/10.1016/S0014-2921(01)00187-8

[3] Easterly, W. (2003) Can Foreign Aid Buy Growth? Journal of Economic Perspectives, 17, 23-24. http://dx.doi.org/10.1257/089533003769204344

[4] Shah, S.A.H., Ahmad, I. and Zahid, M.S. (2005) Is Foreign Aid Necessary for the Economic Development of Less Developed Countries with Special Reference to Pakistan?

[5] Moreira, S.B. (2005) Evaluating the Impact of Foreign Aid on Economic Growth: A Cross-Country Study. Journal of Economic Development, 30, 25.

[6] Veiderpass, A. and Andersson, P.-Å. (2007) Foreign Aid, Economic Growth and Efficiency Development. A Data Envelopment Analysis Approach. Sadev Report 2007:01.

[7] Ekanayake, E.M. and Chatrna, D. (2007) The Effect of Foreign Aid on Economic Growth in Developing Countries. Journal of International Business and Cultural Studies.

[8] Minoiu, C. and Reddy, S.G. (2009) Development Aid and Economic Growth: A Positive Long-Run Relation. International Monetary Fund WP/09/118.

[9] Javid, M. and Qayyum, A. (2011) Foreign Aid and Growth Nexus in Pakistan: The Role of Macroeconomic Policies. PIDE Working Papers 2011:72.

[10] Fasanya, I.O. and Onakoya, A.B. (2012) Does Foreign Aid Accelerate Economic Growth? An Empirical Analysis for Nigeria. International Journal of Economics and Financial Issues, 2, 423-431. 